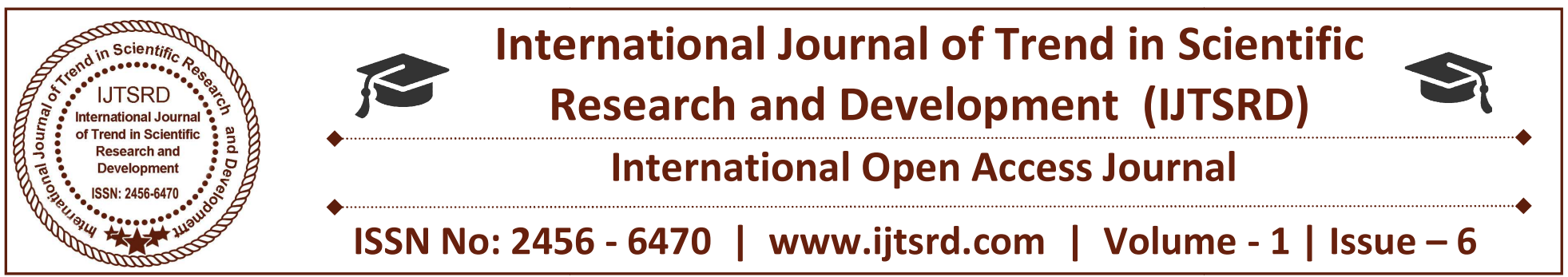

\title{
Student Services Survey
}

\author{
G. Sri Sankari \\ Computer Application, University College of \\ Engineering (BIT Campus), Trichy, India
}

\author{
Dr. A. Valarmathi \\ Computer Application, University College of \\ Engineering (BIT Campus), Trichy, India
}

\section{ABSTRACT}

Student service survey is a journal which describes many journal related to students affairs and to know about the dean of men and dean of women, and to learn about the students affairs. To know briefly about academic advising, academic support services, admission, campus actives, carrier service, counselling, disability services, financial aids, Greek aids, housing life, residential life, judicial services, multicultural, orientation, recreation, intramural, religious and so on.

Keywords: Counselling, affairs, conduct, orientation, Professional

\section{INTRODUCTION}

Student's affair is an important department in all colleges or universities. This department is responsible for all the behaviors of a student in that concern. Professional is taking the responsibility to take care of each and every student. The students can get any idea from the department and they can enhance themselves. Student's affairs should be able to give any information to the student according to their requirements. Students should be able to cooperate with the professional in all sectors, their communication should be reliable and well discipline. Student affairs comprise many titles. This journals aim is to get knowledge from journals related to student's affairs in different colleges and to know about the culture they follow. We have started to read about student's affair to develop the department in our concern. At the end of this survey we hope we can find many use full things to enhance ourselves.

\section{Student Service}

Student service is also called as student's affairs or students support centers. It's a department in higher educations which provides helps for the student's to enhance their ability and even to secure them from the unwanted harassments. The persons who works in this sector is called as professionals or practitioners. These kinds of student's service department is available in all colleges and universities in India and also in all countries. The size of the department is based on the size of the institution. The main aim of the student's service is to help the students in their carrier and also to teach the traditions of the college and even they can mold the behaviors of the students, the department helps the women students to protect them from the sexual harassments and they even teach to protect themselves. Student's affairs supports anti ragging in colleges and universities.

\section{HISTORY}

Now a day's Students service department now exists in all colleges and universities, but this was started in $19^{\text {th }}$ century, at Anglo-American, as an aim to develop the dean of men and dean of women in the Europe countries. Later it spread South Africa, United Kingdom and United states to enhance student's affairs administration and the dean of men and women. In 1960's the student's affairs bought a study on students as a whole or part of mental and 
emotional. In 1970's they reduce the voting age of students to eighteen and granted adult status.

Service Professional

The person who are working in the department of student's service or student's support centers are called as service professionals. They guide the students to enhance their life in the colleges and universities and also in their residential life's, they gave counselling to the students in all aspects of life like administration, employment, campus life, traditions, anti-ragging, leadership and many. There exists many degrees to the professionals, the degree includes counseling, group working, social and cultural development, crisis management and now they are also developing the students in the view of placements.

\section{Literature Survey}

Journal of Student's affairs 2015-2016 volume XxV has states the mission of Colorado State University states their mission as The mission of the Colorado State University Journal of Student Affairs is to develop and produce a scholarly publication which reflects current national and international education issues and the professional interests of student affairs practitioners. They also have their goals to give The Journal will promote scholarly work and perspectives from graduate students and student affairs professionals, reflecting the importance of professional and academic research and writing in higher education. The Editorial Board of the Journal will offer opportunities for students to develop editorial skills, critical thinking, and writing skills while producing a professional publication. Abstract of them is Lack of professional development opportunities, inadequate supervision and mentoring activities and uneasiness navigating the political higher education arena emerged as key themes. Recommendations for graduate students, professionals, graduate faculty, and program administrators, grounded in a synergistic supervision model, are offered. Finally they concluded as Student affairs professionals play critical roles in higher education and in students' lives. These roles include acting as liaisons who acclimate students to their new surroundings, facilitate their funding, coordinate their housing and extracurricular activities, encourage their growth, develop their leadership skills, explore their career interests, and more. Indeed, new professionals' roles are too valuable not to provide intentional focus on their professional growth. As the experiences of the participants in this study demonstrate, the reasons for departure from the field of student affairs are complex. Understanding the reasons for departure can help student affairs professionals to better prepare graduate students for work in the profession, retain them past the six-year mark.

The Foundations of Student Affairs: A Guide to the Profession Dallas Long Illinois State University, dlong@ilstu.edu describes their abstract to define many departments and states their abstract as Student affairs is a large, complex area of campus operations and is comprised of many departments with professionals from a wide variety of educational backgrounds. Long provides a short history of the student affairs profession, followed by an overview of the departments in a typical student affairs division and the responsibilities and goals of the professionals in those departments. Long also describes the values that guide the work of student affairs professionals and the contemporary challenges they face. The value of student's affairs, educating all the students as student affairs professionals accept that college is a critical period of life during which students discover a meaningful identity and develop core values for how they will perceive and experience their adult lives. This holistic view of education focuses on the growth of the intellectual and emotional capacities of students, as well as their development of a stable sense of identity, interpersonal skills, moral and spiritual values, ethics, career goals and vocational skills, and physical wellness. Subsequently, student affairs professionals deliberately create programs, services, and experiences that will advance the students' growth in one or more dimensions of their lives. Care for students: underlying value is care. Student affairs professionals must ultimately care about the well-being of the students they serve. On a higher level, the value of care is demonstrated through student affairs professionals' advocacy for special groups of students. Student affairs professionals educate university administration and others on the needs of special populations of students in order to change policies or procedures that remedy disadvantages or unfair circumstances. Additionally, care is a fundamental value that student affairs professionals strive to in still in students. This generally takes the form of service learning, as students learn to understand the situations of others and want to advocate on their behalf. Service to the students and to the university, Community, Equality and social justice: Social justice as a value of the 
student affairs profession expands on this concept of equality. Scott Rickard defines social justice as "fairness and equity in the distribution of opportunity, in the treatment of individuals, in the assurance of personal and economic security, and in the protection of civil and human rights." He identifies ways in which student affairs professionals promote social justice in higher education-by ensuring that the campus is committed to remedying policies or procedures which historically disadvantaged groups of people, that the campus serves as a model of fairness and inclusion for all people, and that staff and students are encouraged to recognize and be prepared to remedy inequality within the campus and the surrounding community. Essential completion for student's affairs professional: student affairs professionals must be skilled in a multitude of interpersonal and contextual skills. Eight core competencies, identified by the Council for the Advancement of Standards in Higher Education, are expected of new student affairs professionals. Effectively working with diverse population: Student affairs professionals must develop a sophisticated range of multicultural competencies: appreciation for diversity and a thorough, deep knowledge of the cultural values of the students at their colleges and universities. Community building and Developing: Building a sense of community between students is complex but has many advantages for a college or university. Such benefits include creating a welcoming space for difficult discussions and student learning outside the classroom, bringing the campus together in a time of crisis, reducing unwanted incidents such as vandalism, and creating an enduring loyalty to the college or university after the students have graduated. Conflict resolution: Conflicts may occur between students and faculty over academic performance, between student organizations and the university over speech, access to resources, or institutional culture, or between students and family regarding expectations for programs of study and career decisions. Counselling/Helping: Most student affairs professionals are not trained or licensed counselors, but the overwhelming number of them must develop helping skills because of their direct contact with students. Helping skills are not necessarily intended to address a student's emotional well-being, but to provide the student with coping skills and with the context for making decisions that solve his or her own dilemmas. Counseling and helping skills increase a student affairs professional's capacity to create positive relationships and environments for students. Advising: advisors must have sharp interviewing skills to diagnose why something isn't working for a student and why one option might be a better alternative than another. Love and Estanek identified the advising process that student affairs professionals engaged in advising should follow: identifying the problem (e.g., "I don't like my chemistry class."); gathering information about the problem (e.g., "I don't like my chemistry class because the homework is too difficult, and I'm not interested in it"); proposing solutions (e.g., "Let's do a career inventory test to see if there are careers that interest you that don't require a degree in chemistry."); implementation (e.g., "Let's enroll you in Horticulture this next semester to see if that is a better fit for you."); and evaluation (e.g., "You earned a high $\mathrm{A}$ in the Horticulture class. Do you think horticulture is a good fit for you as a new major?"). Leadership: professional having responsibilities to encourage and take their fear and develop leadership. Citizenship: good citizenship can range from implementing green initiatives to reduce energy consumption, organizing service opportunities in underserved communities, to challenging discriminatory laws and practices. The practice of good citizenship is not limited to the municipality or community in which a person lives - it extends to their participation with their department, campus, and college or university, such as celebrating a colleague's notable accomplishment. Assessment, Functional area of students affair practice, Academic advising: Academic advising is linked to a number of important outcomes, including students' satisfaction with their academic programs, achievement for underprepared and underperforming students, and - arguably most important-student persistence. And also explains many titles like admission care, campus ministry, campus safety, carrier service, community service, learning, dean of students affairs, health service, housing/resident life, judicial, multicultural and students union.

Dukes university states their students life and students affairs as Campus Life provides education, advocacy and support for Duke students through advising, leadership development and experiential education. Campus Life is comprised of nine departments that: work with a multicultural campus community to promote intellectual understanding, acknowledgement, and appreciation of their differences and similarities; advocate for equal access for students and student groups to participate in 
campus activities, including an equitable distribution of support resources for those activities; and promote a seamless integration of the academic and cocurricular sides of the University to promote a holistic, educational experience for students. Outreach programs and services are designed to foster an equitable and engaged university community as well as a culture of broad social and civic understanding. Center for Sexual and Gender Diversity (CSGD) provides education, advocacy, support, and space for lesbian, gay, bisexual, transgender, questioning, and straight-allied students, staff, and faculty at Duke, as well as alumni/ae and members of neighboring communities; and presents educational, cultural, and social opportunities for all students, faculty, staff, and alumni/ae to challenge intolerance and to create a more hospitable campus climate.

\section{The Center for Multicultural Affairs offers} educationally based cross-cultural programs to Duke students, and provides technical support on multicultural issues for the university community. CMA is dedicated to helping multicultural students, and all Duke students, receive the benefits of a firstrate multicultural educational experience by providing programs, services and connections with faculty, staff and alumni to deliver a sound diversity agenda.

Fraternity \& Sorority Life advises, serves and supports 38 nationally affiliated chapters and the general Greek community. In partnership with faculty, staff, alumni, families, and (inter)national organizations, we challenge and educate students in the areas of leadership, cultural awareness, personal and group development, scholarship, and civic responsibility.

International House assists international undergraduate, graduate and professional students and their families with orientation and acclimation; enhances cross-cultural interaction among students, faculty and staff through events, programming and community outreach; and provides advocacy and support for the Duke international community on a broad range of issues.

Jewish Life at Duke is comprised of the Freeman Center and the Rubenstein-Silvers Hillel. The Freeman Center provides a home for Jewish life on campus while the Rubenstein-Silvers Hillel provides exciting and innovative programming throughout the Duke community. The combination works to foster and enrich Jewish life for students, faculty and staff through social, educational, religious and cultural activities.

The Mary Lou Williams Center for Black Culture promotes racial understanding, builds community, and fosters an appreciation for and increased knowledge of Black people, Black history, Black culture, and the vast contributions of people of the African Diaspora. MLWC provides programs and services that contribute to the successful academic and personal development of Black students at Duke, and positively impact the lives of all those whom they encounter.

Muslim Life at Duke is committed to enriching the lives of Duke's Muslim students through programs and services that cater to their spiritual, social and intellectual needs. Through the combined efforts of the Muslim Chaplain and the Muslim Student Association, Muslim Life at Duke provides interfaith, community service and social activism opportunities that allow students to discuss and practice topics related to faith, peace, compassion and understanding in a warm and enriching setting. These events and activities are open to all members of the Duke community as well as the Triangle community.

The University Center Activities and Events supports student programming, leadership exploration, and facility operations for student life, and more than 400 registered student groups on campus. UCAE provides services, support, and opportunities for students to engage in co-curricular experiences that lead to personal development, life-long skills, and meaningful connections with other students, faculty, staff, alumni and others connected to the Duke community.

The Women's Center works to improve the status of women in higher education at Duke. By educating the university community about gender-related issues, addressing matters of particular concern to women, and promoting a campus climate that is safe, healthy, and respectful of all people, the Women's Center enhances all students' academic experiences. In collaboration with student groups and faculty and staff colleagues, the Women's Center offers information, advocacy, technical assistance, referrals, and programming on a variety of gender-related issues, including safety, health, personal and professional development, sexuality, discrimination, harassment, and sexual assault support services. 
The Career Center provides career services of the highest standard to Duke undergraduates, graduate students and alumni of Trinity College, the Pratt School of Engineering and the Graduate School. Working in partnership with faculty and colleagues, and recognizing that each individual has unique needs, our staff members help students and alumni make the most of their Duke Education, resources, and connections; develop career interests and values; and find satisfying work. Further, we build and maintain relationships with alumni and employers who can provide internships and learning opportunities, entry-level positions and opportunities for experienced professionals.

The staff of the Duke Career Center connects members of the university community so that students and alumni can receive career advice and mentoring when they need it and, in turn, help others when they are able.

The Dean of Students Office offers mediation services, responds to emergency situations involving students through 24/7 emergency coverage, offers programs in substance abuse prevention and health promotion, and manages the DukeReach program designed to help faculty find help for students in need and coordinates parent programs. The Dean of Students office advises and refers individual students regarding personal concerns and follows up with student victims of crime, illness, or harassment.

DukeReach (the Office of Case Management) provides direct case management services including interventions, advocacy, referrals and follow-up services for students who are experiencing significant difficulties related to mental health, physical health, and/or psycho-social adjustment. The Assistant and Associate Deans in DukeReach coordinate student services and provides connections with campus departments as well as outside agencies and providers. The Duke Student Wellness Center works to enhance the educational experience for Duke students by addressing substance use and abuse issues and promoting healthy physical, emotional and social development, including issues related to sexual health. The Duke Student Wellness Center is dedicated to fostering a living/learning environment on campus and within the surrounding community that encourages the full development of the individual as an engaged member of the community.
The Office of Student Conduct promotes personal responsibility and encourages honesty, integrity and respect among Duke Students. Student Conduct is responsible for holding undergraduate students accountable for academic and non-academic violations of university policy, which flow from Duke's honor code (the Duke Community Standard). The disciplinary process is designed to be an educational one by which individuals or groups recognize their mistakes and learn from them. Student Conduct also serves as an advocate for and resource to student victims of crime, illness, harassment, or other crises.

Duke Student Health is the primary source for healthcare services for Duke students, including general medical care, basic nutrition counseling, laboratory services, travel/immunization clinics, allergy/immunotherapy clinic, physical therapy, and more. Medical services are provided by boardcertified faculty physicians and by physician assistants, nurse practitioners, and resident physicians under faculty supervision. The Student Health Center is a division of the Department of Community and Family Medicine and a department in the Division of Student Affairs. Student Health provides comprehensive, high quality health care and patient education in an environment that is compassionate, non-judgmental, and respectful of diversity. Student Health maintains a main clinic on West Campus on Flowers Drive, and a satellite clinic on East Campus in Wilson House. Counseling and Psychological Services (CAPS)

Counseling and Psychological Services (CAPS) helps Duke Students enhance strengths and develop abilities to deal with the experiences of living, growing, and learning. CAPS offers many services to Duke undergraduate, graduate, and professional students, including brief individual counseling/psychotherapy, consultation, couples and group counseling, and assistance with referrals. CAPS staff also provides outreach education programs to student groups, particularly programs supportive of at-risk populations. Staff members are available for consultation with faculty concerning students or other matters relating to mental health in the university community. The CAPS staff includes psychologists, clinical social workers, and psychiatrists experienced in working with college-age adults. CAPS staff carefully adhere to professional standards of ethics, privacy and confidentiality. 
Housing, Dining and Residence Life (HDRL) manages all aspects of the university's three-year undergraduate residency requirement. HDRL is responsible for a variety of programs, services and resources, including new-student orientation, housing assignments, community housing services, residential life programming, all aspects of campus dining services, care and maintenance of residential facilities, and much more.

Residential programs are designed to build positive communities that value learning, create new opportunities for faculty engagement, and generate positive social connections. HDRL, student residents and others in the Duke community develop and maintain environments that support classroom learning and stir students to seek learning opportunities in the world around them. We promote opportunities for students to connect with others and develop a strong and enduring sense of belonging; and intentionally provide opportunities for students to grow and develop, especially as they wrestle with issues of identity, autonomy and responsibility. HDRL programs are rooted in the concepts of mutual respect and civility, and recognize and celebrate the dignity and self-worth of all members.

HDRL also manages the facilities operations of all university student residences, which comprise approximately 25 percent of all university space. These responsibilities include all long-range planning, renovations and major projects, managing housekeeping and maintenance efforts, and ensuring that all residence options are safe, secure, comfortable, and well-maintained.

Dining Services manages more than 30 restaurants, cafes and food carts across campus. These food options are open to students, faculty, staff and visitors, and are an integral, innovative and awardwinning part of the overall Duke experience. The goal is to provide healthy and enjoyable food and eating venues to meet student needs.

Resource Administration is a collection of central service units including payroll, finance, human resources, information technology, professional development, assessment and event management. These central services support the work of Student Affairs departments through strategic resource management, collaboration and partnerships with staff and other key stakeholders. Resource Administration staff, services, and activities are focused on strategic planning, budgeting, financial operations, payroll, information technology services, communications, staff recruitment, professional development programs, employee relations, organizational development, and management of administrative facilities.

\section{CONCLUSION}

Student service survey states about the students affairs department in different colleges and universities and also surveyed a lot about the student affairs. The survey can conclude that each and every college should have a department for students affairs to administrate all sorts of problems arise. And they have professional who can support students and they should be eligible to take care of each and every kinds of students. They should teach them about behaviorand how to make them as a leader while they enter to the new world.

\section{REFERENCE}

[1] Journal of student's affairs 2015-2016 volume xxv from Colorado State University

[2] The Foundation of students affairs: a guide to the profession by Dallas Long from Illinois state university, dlong@ilstu.edu, 1-1-2012

[3]Student Affairs Strategic Plan, University of California, San Diego • spring 2012

[4] Student Affairs Related

Resources_HESA_Western Michigan University

[5] Guide to Division of Student Affairs Assessment Planning

[6] Journal of Student Affairs at New York University, Volume XI|2015

[7] http://www.murraystate.edu

[8] https://en.wikipedia.org/wiki/Student_affairs

[9] 2013 Journal of Student Affairs in Africa, ISSN 2307-6267, ISBN 978-1-920677-41-1, JSAA is available open access at: www.jsaa.ac.za

[10] Administration and Student Affairs System, Supervisors:Prof. SamehA.Salem, Prof. Claudio Fornaro, Dr. Paolo Prinetto, Students: Ahmed Adel Awad, Hany Abd EL-Samad, Ahmed HishamSaad, Amro Salem Hassan, RamySaadMohareb.Academic year 2010/11

[11]Journal of Student Affairs at New York University, Volume X|2014

[12] https://studentaffairs.duke.edu/ovp/studentaffairs-departments 
[13]

http://www.northwestern.edu/studentaffairs/assessme $\mathrm{nt}$

[14] http://www.stthomas.edu

[15] https://csd.appstate.edu

[16] http://intranet.bloomu.edu/student-affairs

[17] https://gse.rutgers.edu/academic-programs/edmprograms/college-student-affairs

[18]http://www.bestcounselingdegrees.net

[19] http://www.iitd.ac.in

[20] https://www.annauniv.edu/dsa

\section{Author's Profile}

G.Sri Sankari is a MCA student in University College of engineering BIT campus Trichy. I have pursued my under graduation from Bishop Heber college B.Sc.(Mathematics) 2015, now handling BIT campus's web page as a web page designer. I

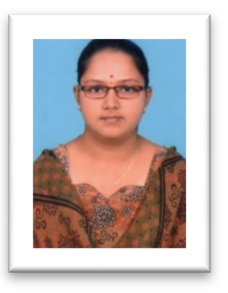
have published my first journal in 2017 by IJSRCSEIT titled as Weather Forecasting with Back Propagation of Neural Network using MATLAB, Sri Sankari G and Dr.A.Valarmathi

Dr.A.Valarmathi is Assistant Professor \& Head, Department of MCA, Anna University, Tiruchirappalli, TamilNadu, India. She pursued her undergraduate in Computer Science from Madurai Kamaraj University, MSc(CS)., MCA

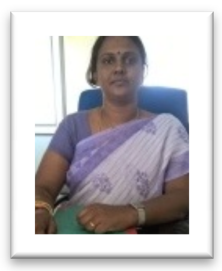
from Bharathidasan University and Annamalai University respectively. She earned her Doctorate in 2013 from Anna University Chennai. Her areas of interest include Mobile computing, Wireless Networks and Bioinformatics. She joined as an Assistant Professor in Anna University, BIT Campus, Tiruchirappalli from 2009. Currently, She is heading the Department of Computer Applications. She has 11 years of teaching experience and she holds the position as a research supervisor of Anna University, Chennai. Presently, she is guiding 10 research scholars and guided for more than $100 \mathrm{MCA}$ \&M.Tech students. She is actively involved in research besides teaching. At present, she is handling Consultancy projects worth of rupees more than 50 lakhs. She has published around 100 papers in International journals and conferences. She presented a paper in an International Conference held in Thiyagaraja College of Engineering which was recognized as a Best Paper. She organized many workshops as part of Quality Improvement Cell supported by IIT-Mumbai and also funded by CSIR and TEQIP. She delivered more than 20 special lectures in Regional and National level workshops and acted as a Session Chair in many National and International conferences. 